\title{
Storage changes in low sodium-processed Mozzarella cheese prepared using potassium-based emulsifying salts
}

\author{
Yogesh Khetra $^{1} \cdot$ Ganesh B. Chavhan $^{1}$. \\ S. K. Kanawjia ${ }^{1} \cdot$ Ritika Puri $^{1}$
}

Received: 31 January 2015 / Revised: 13 July 2015 / Accepted: 16 July 2015 /

Published online: 13 August 2015

(C) INRA and Springer-Verlag France 2015

\begin{abstract}
Dietary sodium has been considered to cause hypertension and other health ailments. Processed Mozzarella cheese (PMC) is a type of processed cheese that contains high sodium in the form of sodium chloride and sodium emulsifying salts. Henceforth, the aim of this study was to investigate the effect of partial substitution of sodium chloride $(\mathrm{NaCl})$ with potassium chloride $(\mathrm{KCl})$ and total replacement of sodium-based emulsifying salts with potassium-based emulsifying salts in the production of experimental PMC. A blend of potassium citrate and dipotassium phosphate (1:1) was used as an emulsifying salt. Changes in sensory attributes, physico-chemical characteristics, and functional properties of PMC were analyzed and compared with the corresponding changes in a control PMC made with $\mathrm{NaCl}$ and trisodium citrate. Products were evaluated after regular intervals of 7 days up to 56 days. Significant differences in flavor (28-56 days), sensory body and texture, acid degree value (0-42 days), soluble protein, titratable acidity (7-56 days), $\mathrm{pH}$ (7-56 days), meltability (0-56 days), and stretchability (4-49) were evident between the control and experimental PMC over storage. It appears that potassium replacement of sodium resulted in a low decrease in casein hydration and an increase in $\mathrm{pH}$ and bitterness. This subsequently resulted in a lower rate of proteolysis, lower flavor scores, lower meltability, lower titratable acidity, lower acid degree values, and greater stretchablity and sensory body and texture scores.
\end{abstract}

This paper is part of the Special issue dedicated to the 9th International Cheese Symposium held in Cork, Ireland and organized by Teagasc in collaboration with University College Cork and INRA, 12th \& 13th November 2014.

Yogesh Khetra

yogesh.khetra@gmail.com

Ganesh B. Chavhan

ganeshchavan74@gmail.com

S. K. Kanawjia

skkanawjia@rediffmail.com

Ritika Puri

ritika02foodtech@gmail.com

1 Dairy Technology, National Dairy Research Institute, Karnal, Haryana 132001, India 
Keywords Emulsifying salts $\cdot$ Potassium chloride $\cdot$ Processed Mozzarella cheese $\cdot$ Low sodium $\cdot$ Meltability $\cdot$ Stretchability

\section{Introduction}

Sodium chloride $(\mathrm{NaCl})$ is added to cheese with the primary purpose to provide flavor and to control the growth of non-starter lactic acid bacteria. Besides these, it also plays major role in controlling the body and texture of cheese. Thus, $\mathrm{NaCl}$ is considered a vital ingredient in cheese (Guinee and Fox 2004). However, excess dietary sodium has been known to cause hypertension which may lead to cardiovascular diseases. As per WHO (2012), the recommended daily intake for sodium is $2.0 \mathrm{~g}$, equivalent to $5.0 \mathrm{~g}$ of $\mathrm{NaCl}$. However, daily sodium intake in most parts of the world is well in excess of this recommendation. Processed cheese contains $1,320 \mathrm{mg}$ Na per $100 \mathrm{~g}$ cheese (Liem et al. 2011) and thus significantly contributes to the percentage of total daily sodium intake in part of a daily diet.

Processed Mozzarella cheese (PMC) is a type of processed cheese known for its meltability, stretchability, and shredability in pizza making and is very popular in India due to the large preferences for processed forms of cheese (Chavhan et al. 2014). It is prepared by heating and shearing of Mozzarella cheese in the presence of emulsifying salts. Monovalent cations and polyvalent anions make the basic structure of emulsifying salts wherein cations are mostly sodium based and therefore contribute to increased sodium content of PMC.

Several researchers have attempted to reduce the amount of salt addition in processed cheese, but such approaches have increased proteolysis and acidity resulting in a soft, pasty, and/or bitter cheese (Johnson et al. 2009). It also effects protein hydration which has major influence on the structure, physico-chemical stability, and physical properties of cheese. Addition of potassium salts to cheeses may result in higher $\mathrm{pH}$, decreased hardness and cohesiveness, a slight increase in fat globule size, and increased flowability (El-Bakry et al. 2011). Such an influence on cheese properties could be related to differences in hydration of the cations with direct influence on casein interactions and fat emulsification.

Partial substitution of $\mathrm{NaCl}$ has been successfully attempted by using $\mathrm{KCl}$ and $\mathrm{NaCl}$ in equal proportion to produce acceptable cheeses. Efforts have been made to assess the physico-chemical, biochemical, textural, and functional changes occurring during storage in cheeses containing potassium as a partial or full replacement of sodium. Studies have monitored lipolysis in Feta cheese (Katsiari et al. 2000a), proteolysis in Feta cheese (Katsiari et al. 2000b) and Kefalograviera cheese (Katsiari et al. 2001), and chemical and functional changes in low-moisture Mozzarella cheese (Ayyash and Shah 2011) prepared with partial replacement of $\mathrm{NaCl}$ with $\mathrm{KCl}$. Efforts have been made to produce processed cheese based on Cheddar using potassium-based emulsifying salts. Karahadian and Lindsay (1984) reported that the production of an acceptable processed cheese using potassium citrates and phosphates. Hoffmann et al. (2012) manufactured pasteurized block-type processed cheese with partial substitution of sodium by potassium in emulsifying salts with no significant loss of functional properties or sensory quality was observed as the bitter taste of potassium-containing salts was barely perceptible in the processed cheeses. Chavhan et al. (2014) reported manufacture of low sodium-processed cheese from Mozzarella employing combined approach of 
partial substitution of $\mathrm{NaCl}$ with $\mathrm{KCl}$ and using potassium based emulsifying salts. The study reported that $70 \%$ reduction in overall sodium content through substitution of $\mathrm{NaCl}$ with $\mathrm{KCl}$ was possible without compromising sensory, textural, and functional attributes.

The objective of the present study was to determine and compare sensory, physicochemical, and functional changes in PMC prepared with potassium-based emulsifying salts and mixtures of $\mathrm{NaCl}$ and $\mathrm{KCl}$ already optimized in the previous study of Chavhan et al. (2014) to that of control PMC (processed cheese made with $\mathrm{NaCl}$ and sodium-based emulsifying salts) during storage.

\section{Materials and methods}

\subsection{Raw material}

Buffalo's fresh milk was procured from Experimental Dairy, National Dairy Research Institute, Karnal (Haryana), India. Microbial rennet (Meito) obtained from Mucor pusillus var. Lindt was procured from Meito Sangyo and Co. Ltd., Tokyo, Japan. Sodium chloride was procured from M/S Tata chemicals, Mumbai, India. Commercial food grade $\mathrm{KCl}$ was purchased from Polypharma Pvt. Ltd. Mumbai, India. Potassium citrate and di-potassium phosphate were procured from $\mathrm{J} \mathrm{K}$ Brothers Ltd. and Arti Phosphates Pvt Ltd., Mumbai, India, respectively. All other chemicals used were of analytical reagent grade.

\subsection{Preparation of PMC}

Processed cheese used in this study was manufactured using Mozzarella cheese as base. Mozzarella cheese was manufactured from buffalo milk by direct acidification method (Jensen et al. 1987) with certain modifications (Chavhan et al. 2014). Standardized milk was acidified at $7{ }^{\circ} \mathrm{C}$, followed by rennet addition at $25{ }^{\circ} \mathrm{C}$. Set curd was cut, cooked, plasticized, and molded as per the method used by Chavhan et al. (2014). This unsalted Mozzarella cheese was used as a base for manufacturing processed cheese.

For manufacturing $\mathrm{PMC}$, a mixture of $\mathrm{NaCl}$ and $\mathrm{KCl}$ was used in the ratio of 70:30 on weight basis. Total salt content was kept at 1\%. Emulsifying salt used in the study comprised a blend of potassium citrate and dipotassium phosphate (hereafter, referred to as emulsifying salt) in the ratio of 1:1. Level of emulsifying salt was kept at $2.0 \%$. These levels were optimized in a similar study by Chavhan et al. (2014). Finely grated Mozzarella cheese was heated in a heating kettle, and as soon as the temperature reached $50{ }^{\circ} \mathrm{C}$, salt mixture $(\mathrm{NaCl}$ and $\mathrm{KCl})$ and emulsifying salt were added to it. The mixture was processed at $75{ }^{\circ} \mathrm{C}$ for 5 min followed by transfer to moulds. PMC was allowed to cool to ambient temperature $\left(25^{\circ} \mathrm{C}\right)$ and cut into blocks of $250 \mathrm{~g}$ and packed in KPA-Cryovac ${ }^{\circledR}$ packages. The packed product was kept at $5{ }^{\circ} \mathrm{C}$ for storage and further analyses. Storage changes in low sodium PMC were compared to a control (full sodium $\mathrm{PMC}$ ) which was prepared by using $1 \% \mathrm{NaCl}$ and $2 \%$ tri-sodium citrate and stored under same conditions. Moisture, fat, protein, and sodium content of control and experimental PMC were 46.95, 20.72, and 26.02\% and $905 \mathrm{mg}$ per $100 \mathrm{~g}$ and 46.18, 20.27, and $27.74 \%$ and $260 \mathrm{mg}$ per $100 \mathrm{~g}$, respectively. 


\subsection{Physico-chemical analysis}

\subsubsection{Titratable acidity and $\mathrm{pH}$}

The titratable acidity of the cheese was determined according to AOAC (1984). For $\mathrm{pH}$ estimation, $10 \mathrm{~g}$ of cheese was macerated with $10 \mathrm{~mL}$ of distilled water and the $\mathrm{pH}$ of resultant slurry was measured using microprocessor controlled pH Anlyser (LabIndia, New Delhi, Version I) with combined glass electrode.

\subsubsection{Acid degree value}

Acid degree value (ADV) was carried out by the method suggested by Deeth and FitzGerald (1976). Samples were prepared by mixing $5 \mathrm{~g}$ of grated cheese with $37.5 \mathrm{~mL}$ of $2 \%$ sodium citrate at $50^{\circ} \mathrm{C}$. Exactly $35 \mathrm{~mL}$ of this extract was used for ADV estimation.

\subsubsection{Soluble protein}

The soluble protein of cheese samples was determined following the procedure delineated by Kosikowski (1982) with some modifications. Approximately $3.0 \mathrm{~g}$ of cheese sample was accurately weighed and mixed with a small amount of Sharp's extraction solution at $40{ }^{\circ} \mathrm{C}$. The volume was made up with Sharp's extraction solution (glacial acetic acid and sodium chloride) to $50 \mathrm{~mL}$. After keeping for $1 \mathrm{~h}$ in water bath at 50 $55{ }^{\circ} \mathrm{C}$, solution was filtered through Whatman Filter Paper No. 42. Twenty-five milliliters of this filtrate was further used for soluble nitrogen estimation using Kjeldahl method (IDF, 1986).

\subsection{Functionality}

\subsubsection{Meltability}

Meltability was determined by the method of Oberg et al. (1993). Ten grams shredded cheese was added into a Pyrex glass tube $(32 \mathrm{~mm} \times 250 \mathrm{~mm})$ and gently tapped with a spatula until each of the samples occupied a length of about $3.5 \mathrm{~cm}$. The one end of the tubes were sealed with stoppers (silicon rubber) and the other with aluminum foil having a small hole to allow gas to escape. The tubes were tempered at $4{ }^{\circ} \mathrm{C}$ for $30 \mathrm{~min}$ in a vertical position and then placed horizontally in an oven at $100{ }^{\circ} \mathrm{C}$ for $60 \mathrm{~min}$. After cooling to room temperature, the length of melted cheese was recorded.

\subsubsection{Stretchability}

Stretchability of PMC was measured on pizza by following the procedure described by Walsh et al. (1998). Shredded cheese $\left(0.25 \mathrm{~g} . \mathrm{cm}^{2}\right)$ was evenly distributed on the pizza base that was pre-cut in half, and it was placed in an oven at $280{ }^{\circ} \mathrm{C}$ for $4 \mathrm{~min}$ and then evaluated for stretchability. One half of the pizza was clamped, and the unclamped section was manually pulled until the extended cheese string joining both section of pizza base broke. The stretch was recorded by measuring the distance between the pizza halves. 


\subsection{Sensory analysis}

The control and experimental PMC were presented for sensory evaluation to a panel of eight trained judges from Dairy Technology Division of National Dairy Research Institute, Karnal. All the judges were trained sensory analyst with a minimum 5 years' experience. A descriptive sensory score card with 90-point scale was used. Scorecard was developed based on American Dairy Science Association (ADSA) scorecard. However, maximum scores for sensory attributes were modified on the basis of recommendation of sensory panel. Maximum scores for flavor, body and texture, and color and appearance were 50,30, and 10, respectively. The samples were presented in random order to eliminate carry over effects. The tests were carried out in individual booths under white light. Judges received approximately $20 \mathrm{~g}$ of each sample, served at the refrigeration temperature $\left(7^{\circ} \mathrm{C}\right)$ in disposable plastic cups coded with random three-digit numbers.

\subsection{Statistical analysis}

Product manufacturing trials were conducted in triplicate. However, reported results pertain to only one trial as there was non-significant difference among the replicate trials. The presented values are mean of three replicate analysis. The data were analyzed with SAS ver. 5.3 (SAS Institute Inc., Cary, NC). One-way analysis of variance was performed to investigate significant difference at 5\% level of significance between control and experimental cheeses at same storage period and to examine the significance of storage period within a salt treatment. Post hoc analysis for finding out significantly different treatment was carried out using Tukey HSD technique.

\section{Results and discussion}

\subsection{Sensorial changes during storage of PMC}

Organoleptic scoring of control and experimental PMC are demonstrated in Fig. 1(a). A statistically significant $(p<0.05)$ effect of storage on flavor scores of control and experimental PMC was found. There was no significant difference in the flavor scores of control and experimental PMC up to 28 days of storage, but scores were statistically higher for the control after day 28. Up to 28 days, these results are in agreement with the findings of Katsiari et al. (1998) who reported no significant difference in the flavor between different Kefalograviera cheeses made with varying $\mathrm{NaCl}$ to $\mathrm{KCl}$ mixture (1:1) as compared to full sodium counterpart. After 28 days, experimental PMC obtained significantly lower $(p<0.05)$ scores for flavor due to the development of bitterness which has often been described with the use of potassium salts in cheese (Chavhan et al. 2014). Ayyash et al. (2012) studied the sensory attributes of Akawi cheese prepared with different proportions of $\mathrm{NaCl}$ and $\mathrm{KCl}$ and found significantly more bitterness for the samples containing $\mathrm{NaCl}$ to $\mathrm{KCl}$ (1:3) mixture during storage of 30 days.

Body and texture scores of both control and experimental PMC showed a significant $(p<0.05)$ decreasing trend during storage as represented in Fig. 1(b), but remained above the minimum acceptable limits, usually $65 \%$ score (Londhe et al. 2012) of the 
total score during storage. Body and texture score of control and experimental PMC differed significantly $(p<0.05)$ throughout storage with a higher score for experimental PMC which was reported to be firmer. The difference was apparent from day zero. Experimental PMC had higher score possibly due to more extensive casein-casein interactions (Sheehan and Guinee 2004) as it is likely that to have more colloidal calcium phosphate because the cation exchange between calcium and potassium is less than sodium and calcium resulting in less soluble calcium (Carr et al. 2002).

The color and appearance of cheese is also important for consumer acceptance. Figure 1(c) shows a significant $(p<0.05)$ decrease in color and appearance scores of both the PMC with storage; however, there was no significant $(p>0.05)$ difference in both treatments.

\subsection{Physico-chemical changes during storage of PMC}

The physico-chemical changes in PMC during storage are shown in Fig. 2(a). The pH of the control and experimental PMC significantly $(p<0.05)$ decreased during storage. Experimental PMC had consistently significant higher $\mathrm{pH}$ values than the control, similar to results by Katsiari et al. (1998) and Ayyash and Shah (2011) for Kefalograviera and low-moisture Mozzarella cheese, respectively. This may be due

(a)

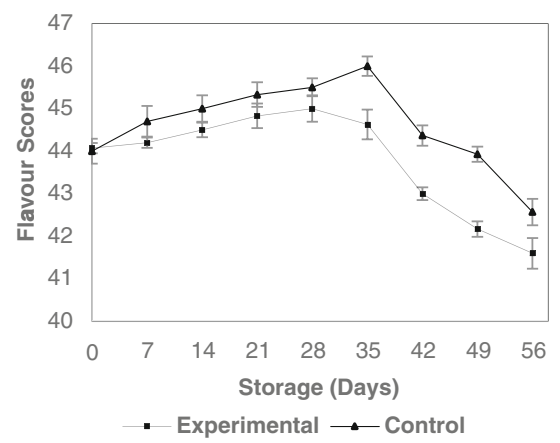

(b)

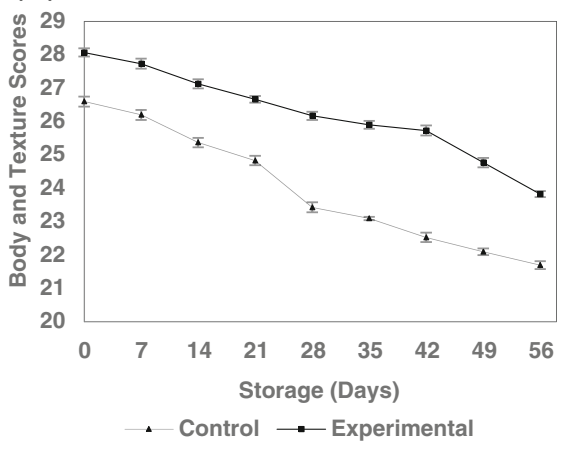

(c)

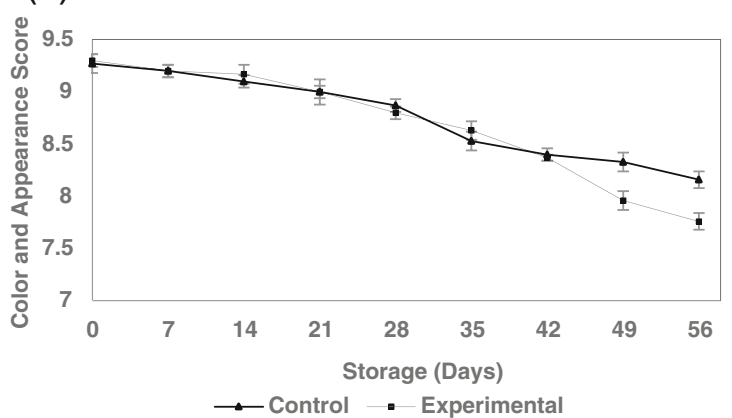

Fig. 1 Evolution in sensory scores of control and experimental PMC during storage a change in flavor, b change in body and texture, and c change in color and appearance (values represented are means of three replicates with their standard errors) 
to the fact that $\mathrm{KCl}$ solution has 0.3 values higher for $\mathrm{pH}$ as compared to an equivalent solution of $\mathrm{NaCl}$. This might be a possible reason for higher $\mathrm{pH}$ of experimental cheese. In agreement with $\mathrm{pH}$, the titratable acidity of both the control and experimental PMC increased significantly $(p<0.05)$ with storage, in which the control PMC had consistently higher value (Fig. 2(b)). Control and experimental PMC had no significant $(p>0.05)$ differences in titratable acidity until after 7 days.

Enzymatic hydrolysis of triglycerides to fatty acids and glycerol, mono-, or diglycerides is considered an essential factor for flavor development in cheese (McSweeney and Sousa 2000). Lipolysis is a critical biochemical event during cheese ripening which has been studied extensively in different varieties. The ADVs of control and experimental PMC are given in Fig. 2(c). The ADV increased in both types of cheeses during storage similar to titratable acidity. The control was significantly higher up to 42 days of storage, however at the end of storage the difference was not significant ( $p>0.05$; Fig. 2(c)) and in agreement with studies by Katsiari et al. (2000a) and Reddy and Marth (1994) for Feta cheese and Cheddar cheese, respectively.

Proteolysis is the most complex and, in most varieties, the most important of the three primary biochemical events which occur in cheese during ripening. It promotes texture development and flavor development in cheese. It is catalysed by proteinases and peptidases from different sources such as milk coagulant, milk plasmin, starter

(a)

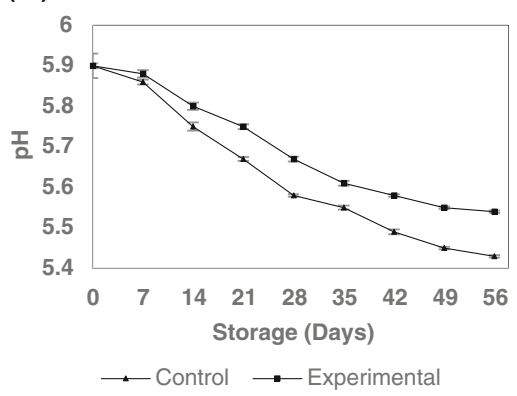

(c)

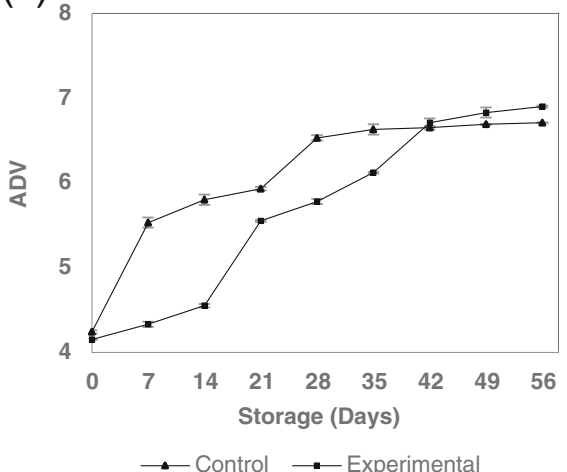

(b)

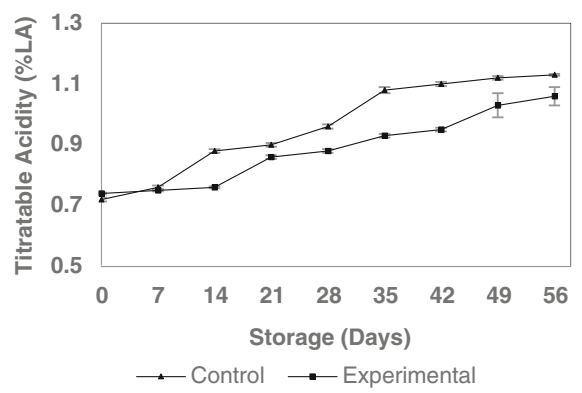

(d)

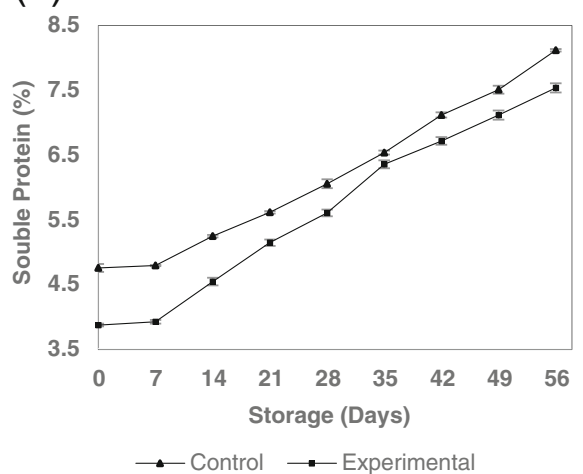

Fig. 2 Evolution in physico-chemical characteristics of control and experimental PMC during storage a change in $\mathrm{pH}, \mathbf{b}$ change in titratable acidity, $\mathbf{c}$ change in ADV, and $\mathbf{d}$ change in \% soluble protein (values represented are means of three replicates with their standard errors) 
lactic acid bacteria, non-starter lactic acid bacteria, and secondary starters. It is evident from Fig. 2(d) that the soluble protein content of control and experimental PMC increased significantly $(p<0.05)$ during storage of 56 days and was higher $(p<0.05)$ in control PMC. Increased proteolysis in low-sodium Minas fresh cheese (Gomes et al. 2011), Akawi cheese containing $\mathrm{NaCl}$ substituted $\mathrm{KCl}$ (Ayyash et al. 2012), and reduced sodium Feta cheese (Katsiari et al. 2000b) during storage corroborates these findings. Sheehan and Guinee (2004) studied the effect of calcium content and $\mathrm{pH}$ on proteolysis in low moisture Mozzarella cheese during 70 days storage. They reported that at similar $\mathrm{pH}$ values, higher proteolysis in cheese having lower calcium to casein ratios may occur. Higher cation exchange capacity of sodium may result in larger conversion of colloidal calcium to soluble calcium (Carr et al. 2002) which exposes the casein-casein interactions for action by proteinases; perhaps due to this, control PMC had higher proteolysis (Feeney et al. 2002). Sheehan and Guinee (2004) also observed lower proteolysis in cheese having a higher $\mathrm{pH}$, low moisture in non-fat substances, and lower rennet retention in curd. In our study, higher $\mathrm{pH}$ values due to $\mathrm{KCl}$ addition to experimental PMC might have resulted in less favorable conditions for the activity of residual rennet in proteolysis of cheese during storage (Mulvihill and Fox 1980). Also as evident from proximate composition of control and experimental PMC, the moisture content of latter was lower which may have retarded microbial growth. Less proteolysis of experimental PMC could also be possible due to the variable proteolytic activity of non-starter lactic acid bacteria.

\subsection{Functional changes during storage of PMC}

Meltability and stretchability are important functional properties of Mozzarella cheese which determine its suitability as an ingredient in pizza making. Meltability is defined as the ease with which cheese flows or spreads upon heating (Muthukumarappan et al. 1999). Interactions between casein molecules govern melting and stretching properties of cheese (Lucey et al. 2003). Sodium promotes casein hydration and thus facilitates interactions between casein and entrapped fat globules which decreases meltability due to casein emulsification (Kinsella and Melachouris 1976). Fat in milk plays an important role in attributing functionality to cheese, as it has been reported that homogenized cheese milk leads to cross-linking of casein on the fat globule surface with the casein in the matrix, preventing the cheese from melting (Tunick et al. 1995). However, with decreasing casein-casein interaction due to solubilization of colloidal calcium phosphate to soluble calcium due to the exchange with sodium, meltability of cheese may increase. Meltability of control and experimental PMC during storage increased significantly $(p<0.05)$ and differed significantly in both treatments $(p<0.05)$ during storage with more pronounced results for control PMC. Figure 3(a, b) elaborates the effect of storage on meltability and stretchability of control and experimental PMC. Low-moisture Mozzarella cheese prepared with substitution of $\mathrm{NaCl}$ with $\mathrm{KCl}$ was observed to have increased meltability with storage (Ayyash and Shah 2011). This increase may be attributed to two factors: (1) an increase in proteolysis during storage, (Kindstedt et al. 2004) and (2) an increase in the conversion of insoluble calcium to soluble calcium, which in turn reduced the strength between casein networks (Feeney et al. 2002). Higher meltability in control cheese was possibly due to less proteinprotein interaction owing to more calcium sequestration by trisodium citrate (Swenson 
(a)

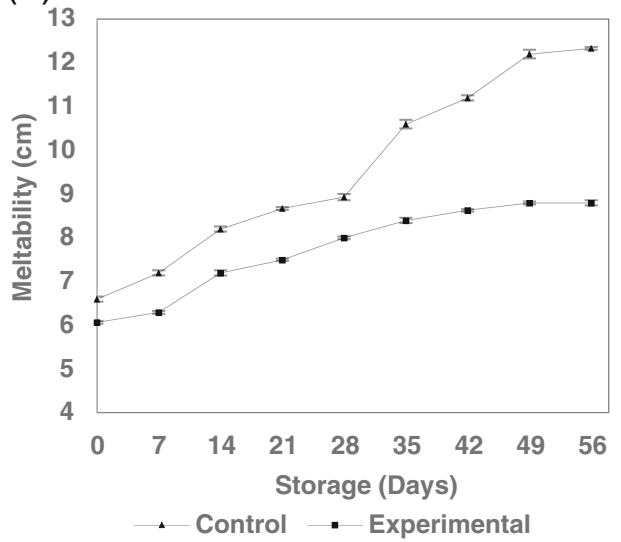

(b)

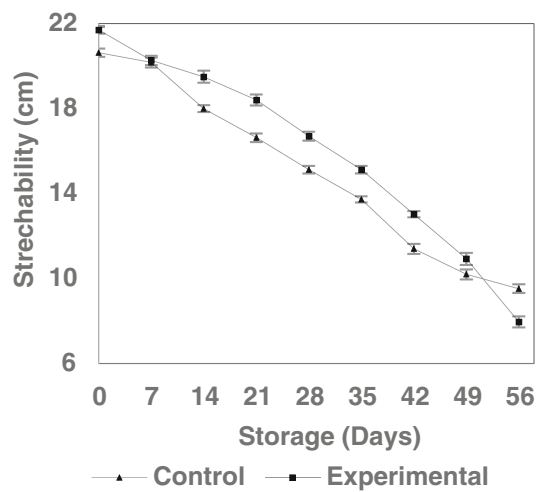

Fig. 3 Evolution in $\mathbf{a}$ meltability and $\mathbf{b}$ stretchability of control and experimental PMC during storage (values represented are means of three replicates with their standard errors)

et al. 2000). Also in a study by Carr et al. (2002), it was suggested that according to Hofmeister series, sodium ions have more hydration tendency as compared to potassium which means sodium competes more effectively with protein for existing water and causes higher solubilization of colloidal calcium and in turn higher casein hydration. This enhances the heat-induced displacement of adjacent layers of the para-casein matrix on heating which increases meltability (Sheehan and Guinee 2004). Less casein hydration in case of experimental cheese due to lower ratio of soluble to colloidal calcium thus leads to less soluble casein having comparatively stronger protein-protein interaction which in turn may reduce meltability of experimental PMC (El-Bakry et al. 2011).

Stretch is the ability of the casein network to continuously maintain its integrity without breaking when uninterrupted stress is applied to the cheese. Casein molecules have the capability to interact with each other for good stretch; consequently, they should release stress which is applied and become pliable, i.e. should not break (Lucey et al. 2003). It is known that for good stretching properties, relatively high concentrations of intact casein and critical concentrations of $\mathrm{Ca}$ and $\mathrm{P}$ are required (Lucey and Fox 1993). The stretchability of control and experimental PMC showed a significant $(p<0.05)$ decreasing trend with storage. The stretchability of the control was significantly $(p<0.05)$ lower that the experimental PMC from 0 to 49 days. Kindstedt et al. (2004) and Kuo et al (2003) also reported a decrease in the stretchability of Mozzarella cheese during ripening, which may be due to plasmin activity, especially if the curd has not been subjected to a high heat treatment in the cooker or stretcher or cheese has been stored at very low temperatures (Lucey et al. 2003). Lower stretchability values of control PMC from 0 to 49 days could be the reason of weaker protein-protein interaction between casein particles attributed to the extensive solubilization of colloidal calcium phosphate in the presence of sodium ions during brining (El-Bakry et al. 2011) and possibly calcium sequestration by trisodium citrate salt which lead to formation of solubilized calcium and exposed casein which might have weaker strength between protein-protein linkages and thus resulted in lower stretchability. 


\section{Conclusion}

It can be concluded from the present investigation that some sensory, physico-chemical, and functional properties of full sodium (control) and low sodium (experimental) PMC varied significantly during storage. Experimental PMC had lower proteolysis and thus lower flavor score and firmer body. It appears that calcium content and final $\mathrm{pH}$ of PMC may be playing an important role in governing these changes. Lower meltability and inversely higher stretchability for experimental PMC could be the reason of altered protein-protein interaction as a consequence of potassium based emulsifying salts and lower cation exchange and hydration tendency of potassium ion according to Hofmeister series.1

Acknowledgement Thankful acknowledgement to the Director, National Dairy Research Institute for providing economic assistance in the form of Institute Research Project and other infrastructural amenities for conducting the presented research work.

Conflict of interest Yogesh Khetra, Ganesh B. Chavhan, S.K. Kanawjia, and Ritika Puri have no conflict of interest.

\section{References}

AOAC (1984) Official methods of analysis. Association of Official Analytical Chemists, Washington DC Ayyash MM, Shah NP (2011) The effect of substitution of $\mathrm{NaCl}$ with $\mathrm{KCl}$ on chemical composition and functional properties of low-moisture Mozzarella cheese. J Dairy Sci 94:3761-3768

Ayyash MM, Sherkat F, Shah NP (2012) The effect of NaCl substitution with KCl on Akawi cheese: chemical composition, proteolysis, angiotensin-converting enzyme-inhibitory activity, probiotic survival, texture profile, and sensory properties. J Dairy Sci 95:4747-4759

Carr AJ, Munro PA, Campanella OH (2002) Effect of added monovalent or divalent cations on the rheology of sodium caseinate solutions. Int Dairy J 12:487-492

Chavhan GB, Kanawjia SK, Khetra Y, Puri R (2014) Effect of potassium-based emulsifying salts on sensory, textural, and functional attributes of low-sodium processed Mozzarella cheese. Dairy Sci Technol 95:265278

Deeth HC, Fitz-Gerald CH (1976) Lipolysis in dairy products: a review. Aust J Dairy Technol 31:53-64

El-Bakry M, Duggan E, O'Riordan ED, O’Sullivan M (2011) Effect of cation, sodium or potassium, on casein hydration and fat emulsification during imitation cheese manufacture and post-manufacture functionality. LWT-Food Sci Technol 44:2012-2018

Feeney EP, Guinee TP, Fox PF (2002) Effect of pH and calcium concentration on proteolysis in Mozzarella cheese. J Dairy Sci 85:1646-1654

Gomes AP, Cruz AG, Cadena RS, Celeghini RMS, Faria JAF, Bolini HMA, Pollonio MAR, Granato D (2011) Manufacture of low-sodium Minas fresh cheese: effect of the partial replacement of sodium chloride with potassium chloride. J Dairy Sci 94:2701-2706

Guinee TP, Fox PF (2004) Salt in cheese: physical, chemical and biological aspects. In: Fox PF, McSweeney PLH, Cogan TM, Guinee TP (eds) Cheese: chemistry, physics and microbiology 1., pp 207-259

Hoffmann W, Gärtner J, Lück K, Johannsen N, Maurer A (2012) Effect of emulsifying salts containing potassium on the quality of block-type processed cheese. Int Dairy J 25:66-72

IDF (1986) Determination of nitrogen content (Kjeldahl method) and calculation of crude protein content Internat. Dairy Fed Standard 20A(1986)

Jensen LA, Johnson ME, Olson NF (1987) Use of glucono-delta-lactone as an acidulant for low moisture part skim Mozzarella cheese produced from ultrafiltered milk. J Dairy Sci 70:66-66

Johnson ME, Kapoor R, McMahon DJ, McCoy DR, Narasimmon RG (2009) Reduction of sodium and fat levels in natural and processed cheeses: scientific and technological aspects. Compr Rev Food Sci F 8: 252-268 
Karahadian C, Lindsay RC (1984) Flavor and textural properties of reduced-sodium process American cheeses. J Dairy Sci 67:1892-1904

Katsiari MC, Voutsinas LP, Alichanidis E, Roussis IG (1998) Manufacture of Kefalograviera cheese with less sodium by partial replacement of $\mathrm{NaCl}$ with $\mathrm{KCl}$. Food Chem 61:63-70

Katsiari MC, Alichanidis E, Voutsinas LP, Roussis IG (2000a) Proteolysis in reduced sodium Feta cheese made by partial substitution of $\mathrm{NaCl}$ by $\mathrm{KCl}$. Int Dairy $\mathrm{J}$ 10:635-646

Katsiari MC, Voutsinas LP, Alichanidis E, Roussis IG (2000b) Lipolysis in reduced sodium Feta cheese made by partial substitution of $\mathrm{NaCl}$ by $\mathrm{KCl}$. Int Dairy $\mathrm{J}$ 10:369-373

Katsiari MC, Alichanidis E, Voutsinas LP, Roussis IG (2001) Proteolysis in reduced sodium Kefalograviera cheese made by partial replacement of $\mathrm{NaCl}$ with $\mathrm{KCl}$. Food Chem 73:31-43

Kindstedt P, Caric M, Milanovic S (2004) Pasta-filata cheeses. In: Fox PF, McSweeney PLH, Cogan TM, Guinee TP (eds) Cheese: chemistry, physics and microbiology 2, pp 251-277

Kinsella JE, Melachouris N (1976) Functional properties of proteins in foods: a survey. Crit Revs Food Sci Nutr 7:219-280

Kosikowski FV (1982) Whey and whey foods. In: Kosikowski FV (ed) Cheese and fermented milk foods. Edwards Brothers, New York, pp 446-469

Kuo MI, Anderson ME, Gunasekaran S (2003) Determining effects of freezing on pasta filata and non-pasta filata Mozzarella cheeses by nuclear magnetic resonance imaging. J Dairy Sci 86:2525-2536

Liem DG, Miremadi F, Keast RS (2011) Reducing sodium in foods: the effect on flavor. Nutrients 3:694-711

Londhe G, Pal D, Raju PN (2012) Effect of packaging techniques on shelf life of brown peda, a milk-based confection. LWT-Food Sci Technol 47:117-125

Lucey JA, Fox PF (1993) Importance of calcium and phosphate in cheese manufacture: a review. J Dairy Sci $76: 1714-1724$

Lucey JA, Johnson ME, Horne DS (2003) Invited review: perspectives on the basis of the rheology and texture properties of cheese. J Dairy Sci 86:2725-2743

McSweeney PL, Sousa MJ (2000) Biochemical pathways for the production of flavour compounds in cheeses during ripening: a review. Lait 80:293-324

Mulvihill DM, Fox PF (1980) Proteolysis of-casein by chymosin in dilute Nac1 solutions and in cheddar cheese. Irish J Food Sci Technol: 13-23

Muthukumarappan K, Wang YC, Gunasekaran S (1999) Estimating softening point of cheeses. J Dairy Sci 82: 2280-2286

Oberg CJ, McManus WR, McMahon PJ (1993) Microstructure of Mozzarella cheese during manufacturing. Food Struct 12:251-258

Reddy KA, Marth EH (1994) Sensory evaluation of cheddar cheese made with sodium chloride or mixtures of sodium and potassium chloride. J Sensory Stud 9:187-204

Sheehan JJ, Guinee TP (2004) Effect of $\mathrm{pH}$ and calcium level on the biochemical, textural and functional properties of reduced-fat Mozzarella cheese. Int Dairy J 14:161-172

Swenson BJ, Wendorff WL, Lindsay RC (2000) Effects of ingredients on the functionality of fat-free process cheese spreads. J Food Sci 65:822-825

Tunick MH, Malin EL, Smith PW, Holsinger VH (1995) Effects of skim milk homogenization on proteolysis and rheology of Mozzarella cheese. Int Dairy J 5:483-491

Walsh CD, Guinee TP, Harrington D, Mehra R, Murphy JM, Fitzgerald RJ (1998) Cheese making, compositional and functional characteristics of low moisture part-skim Mozzarella cheese from bovine milks containing k-casein AA, AB or BB genetic variants. J Dairy Res 65:307-315

WHO (2012) Guideline: sodium intake for adults and children. World Health Organization (WHO), Geneva 